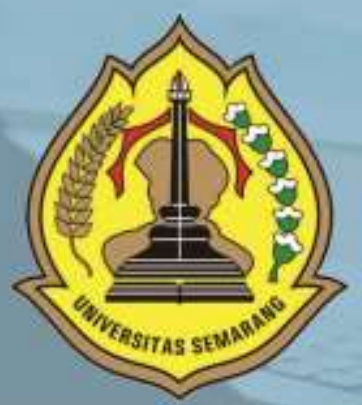

P-ISSN: 1412-5331, E-ISSN: 2716-2532 MAJALAH ILMIAH FAKULTAS EKONOMI UNIVERSITAS SEMARANG

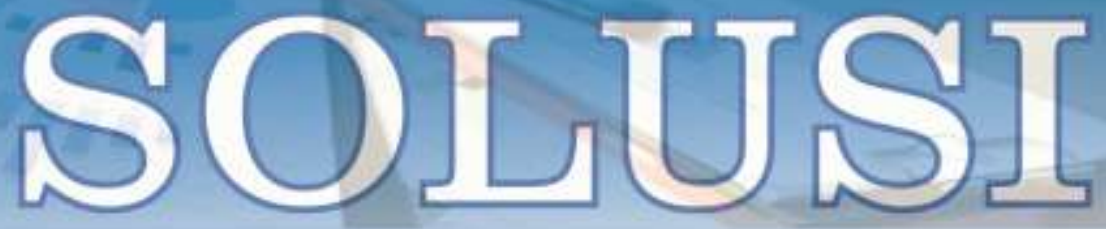

PENGARUH TINGKAT LITERASI KEUANGAN, SIKAP INDIVIDU TERHADAP MINAT INVESTASI SAHAM DI KALANGAN MAHASISWA S2 MAGISTER MANAJEMEN UNIVERSITAS SEMARANG (Asah Wiari Sidiq: Asih Niati - Universitas Semarang)

PENINGKATAN KINERJA PENGAJARAN DOSEN MELALUI KEPEMIMPINAN TRANSFORMASIONAL DAN PEMENUHAN KEBUTUHAN PSIKOLOGIS DASAR DENGAN PEMEDIASI MOTIVASI KER.JA (Anik Herminingsih - Universitas Mercu Buana)

PENGARUH PAJAK, TUNNELING INCENTIVE DAN GOOD CORPORATE GOVERNANCE (GCG) DAN MEKANISME BONUS TERHADAP INDIKASI TRANSFER PRICING PADA PERUSAHAAN MANUFAKTUR (Arum Sasi Andayani; Andiani Ika Sulistyanuati - Liniversitas Semarang)

PENGELOLAAN ALOKASI DANA DESA: AKUNTABILITAS DAN TRANSPARANSI (STUDI KASUS PADA DESA GINGGANGTANI, KECAMATAN GUBUG, KABUPATEN GROBOGAN) (Ana Rokhatt: Saifidin: Dian Trivani - Universitas Semarang)

PENERAPAN STRATEGI BAURAN PEMASARAN PADA USAHA KECIL TELUR ASIN DI KELURAHAN TEGAL SARI, KECAMATAN CANDI SARI, SEMARANG (Nisa Novia Avien Christy; Dwi Widi Pratito - Universitas Semarang)

FAKTOR-FAKTOR YANG MEMPENGARUHI PROFITABILITAS LEMBAGA PERKREDITAN DESA (LPD) DI KABUPATEN BADUNG (Ida Ayu Nyoman Yuliastuti, Putu Kepramareni, I Gusti Ayu Asta Yunisari - Universitas Mahasaraswati Denpasar)

KEBERHASILAN MEMPERTAHANKAN WARUNG MAKAN PRASMANAN MBAH SAN (Sri Wulandari: Susanto - Universitas Semarang)

BRAND PERSONALITY DAN GENDER BRAND PERSONALITY STRATEGI MEMBANGUN MEREK (Haris Murwanto - Universitas Semarang)

POLA PERMINTAN DAN PENAWARAN KETERSEDIAAN DAGING SAPI NASIONAL TAHUN 2030 DENGAN PENDEKATAN FORECASTING (Moeljono - Universitas Semarang)

PENGARUH BRAND IMAGE, KUALITAS PRODUK, PERSEPSI HARGA TERHADAP KEPUTUSAN PEMBELIAN (STUDI KASUS PADA PRODUK SUSU NATURSOYA CV. GLOBAL MANDIRI SEJAHTERA KANCA PURWODADI)

(Ajeng Ayr Fatimah P: Soedarmadi - Untversitas Semarang) 


\section{DESKRIPSI}

Majalah IImiah Solusi Mengkaji

Masalah-Masalah Sosial,

Ekonomi dan Bisnis

\section{KETERANGAN TERBIT}

Terbit Pertama Kali Juli 2002

dan SelanjutnyaTerbit Tiga Bulan

Sekali (Januari, April, Juli dan

Oktober)

\section{PENERBIT}

Fakultas Ekonomi USM

\section{ALAMAT PENERBIT}

JL. Soekarno Hatta Semarang

Telp. 024-6702757 Fax. 024-6702272

\section{PENGELOLA}

Editor in Chief : Yohanes Suhardjo, SE, M.Si., Ak, CA Vice Editor Chief : Sugeng Rianto, SE, MM

Managing Editor: Edy Suryawardana, SE, MM

Secretary of Managing Editor : Asih Niati, SE, MM

Administration \& Circulation :

Citra Rizkiana, SE, MM

Layout \& Typesetting : M Burhan Hanif S.Kom, M.Kom

Board of Editors:

1. Prof. Dr. Ir. Kesi Widjajanti, SE, MM (USM)

2. Prof. Drs. Mohammad Nasir, Msi, Ph.D, AK. (USM)

3. Prof. Supramono SE, MBA, DBA (UKSW)

4. Prof. Drs. H. Imam Ghozali, M.Com, Akt, PhD (UNDIP)

5. Prof. Dr. Agus Suroso, MS (UNSOED)

6. Prof. Dr. Widodo, SE, M.Si (UNISSULA)

7. Prof. Dr. Dra. Sulastri, ME, M.Kom (UNSRI)

8. Dr. Ardiani Ika S, SE, MM, Ak, CA, CPA (USM)

\section{KATA PENGANTAR}

Sungguh merupakan kebahagiaan tersendiri bagi kami, takala kami dapat hadir rutin setiap tiga bulan sekali untuk saling bertukar pikiran mengenai hal-hal baru dibidang sosial, ekonomi dan bisnis.

Pada kesempatan ini penerbit menyampaikan terima kasih kepada semua pihak yang telah mengirimkan artikel-artikelnya. Penerbit akan membuka kesempatan seluas-luasnya bagi seluruh kalangan akademisi maupun praktisi baik dari dalam maupun luar Universitas Semarang untuk mempublikasikan karya ilmiahnya.

Penerbitan majalah ilmiah "SOLUSI" kali ini menghadirkan 10 (Sepuluh) artikel yang kami anggap layak untuk diterbitkan, dengan harapan dapat menjadi tambahan referensi bagi para pembaca dan menjadi sumbangan pengembangan persemaian khasanah pengetahuan dibidang sosial, ekonomi dan bisnis.

Akhir kata semoga majalah ilmiah "SOLUSI" dapat memberi manfaat yang sebesar-besarnya.

Hormat Kami 


\section{DAFTAR ISI}

PENGARUH TINGKAT LITERASI KEUANGAN, SIKAP INDIVIDU

TERHADAP MINAT INVESTASI SAHAM DI KALANGAN MAHASISWA S2 MAGISTER MANAJEMEN UNIVERSITAS SEMARANG

(Asah Wiari Sidiq; Asih Niati - Universitas Semarang).......

PENINGKATAN KINERJA PENGAJARAN DOSEN MELALUI

KEPEMIMPINAN TRANSFORMASIONAL DAN PEMENUHAN KEBUTUHAN PSIKOLOGIS DASAR DENGAN PEMEDIASI MOTIVASI KERJA

(Anik Herminingsih - Universitas Mercu Buana)

PENGARUH PAJAK, TUNNELING INCENTIVE DAN GOOD CORPORATE GOVERNANCE (GCG) DAN MEKANISME BONUS TERHADAP INDIKASI TRANSFER PRICING PADA PERUSAHAAN MANUFAKTUR

(Arum Sasi Andayani; Ardiani Ika Sulistyawati - Universitas Semarang)

PENGELOLAAN ALOKASI DANA DESA: AKUNTABILITAS DAN TRANSPARANSI

(STUDI KASUS PADA DESA GINGGANGTANI, KECAMATAN GUBUG, KABUPATEN GROBOGAN)

(Ana Rokhati; Saifudin; Dian Triyani - Universitas Semarang).

PENERAPAN STRATEGI BAURAN PEMASARAN PADA USAHA KECIL TELUR ASIN DI KELURAHAN TEGAL SARI, KECAMATAN CANDI SARI, SEMARANG

(Nisa Novia Avien Christy; Dwi Widi Pratito - Universitas Semarang)

FAKTOR-FAKTOR YANG MEMPENGARUHI PROFITABILITAS LEMBAGA PERKREDITAN DESA (LPD) DI KABUPATEN BADUNG

(Ida Ayu Nyoman Yuliastuti; Putu Kepramareni; I Gusti Ayu Asta Yunisari - Universitas Mahasaraswati Denpasar)..... .75

KEBERHASILAN MEMPERTAHANKAN WARUNG MAKAN PRASMANAN MBAH SAN

(Sri Wulandari; Susanto - Universitas Semarang).....

BRAND PERSONALITY DAN GENDER BRAND PERSONALITY STRATEGI MEMBANGUN MEREK

(Haris Murwanto - Universitas Semarang).

POLA PERMINTAN DAN PENAWARAN KETERSEDIAAN DAGING SAPI NASIONAL TAHUN 2030 DENGAN PENDEKATAN FORECASTING

(Moeljono - Universitas Semarang)......

PENGARUH BRAND IMAGE, KUALITAS PRODUK, PERSEPSI HARGA TERHADAP KEPUTUSAN PEMBELIAN (STUDI KASUS PADA PRODUK SUSU NATURSOYA CV. GLOBAL MANDIRI SEJAHTERA KANCA PURWODADI)

(Ajeng Ayu Fatimah P; Soedarmadi - Universitas Semarang) 


\title{
PENINGKATAN KINERJA PENGAJARAN DOSEN MELAUI KEPEMIMPINAN TRANSFORMASIONAL DAN PEMENUHAN KEBUTUHAN PSIKOLOGIS DASAR DENGAN PEMEDIASI MOTIVASI KERJA
}

\author{
Anik Herminingsih
}

aherminingsih@gmail.com

\author{
Program Studi Manajemen Universitas Mercu Buana
}

Diterima: November 2019, Disetujui:Desember 2019,Dipublikasikan: Januari 2020

\begin{abstract}
Student satisfaction toward learning process needs attention from the university management because it affects the student loyalty. This study aims to assess and analyze the effect of transformational leadership and fulfillment of the basic psychological needs for the performance of the learning process with the motivation as a mediating variable. A total of 51 lecturers who were selected randomly drawn from 577 lecturers at Mercu Buana University. The primary data obtained through the dissemination of the questionnaire, then processed with a path analysis model using AMOS program. The results showed that the fulfillment of basic psychological needs with dimensions of competence, autonomy and attachment have significant effect on the performance of lecturers in teaching and learning, both directly and through intrinsic motivation as mediating variable.
\end{abstract}

Keywords: intrinsic motivation, competence, autonomy, attachment

\begin{abstract}
ABSTRAK
Kepuasan mahasiswa terhadap proses belajar mengajar perlu mendapat perhatian dari manajemen perguruan tinggi karena mempengaruhi loyalitas mahasiswa. Penelitian ini bertujuan mengkaji dan menganalisis pengaruh kepemimpinan transformasional dan pemenuhan kebutuhan psikologis dasar terhadap kinerja proses belajar mengajar dengan motivasi kerja sebagai variabel pemediasi. Sebanyak 51 orang dosen yang dipilih secara acak diambil dari 577 dosen tetap di Universitas Mercu Buana. Data primer diperoleh melalui penyebaran kuisoner, kemudian diolah dengan model analisis jalur dengan bantuan program AMOS. Hasil penelitian menunjukkan bahwa pemenuhan kebutuhan psikologis dasar dengan dimensi-dimensi kompetensi, otonomi dan keterikatan berpengaruh signifikan terhadap kinerja dosen dalam proses belajar mengajar baik secara langsung maupun melalui motivasi intrinsik sebagai variabel pemediasi. Adapun kepemimpinan transformasional tidak berpengaruh signifikan terhadap motivasi intrinsik maupun terhadap kinerja dosen.
\end{abstract}

Kata kunci : motivasi intrinsik, kompetensi, otonomi, keterikatan

\section{PENDAHULUAN}

\section{Latar Belakang}

Kajian mengenai loyalitas mahasiswa terhadap perguruan tinggi telah mendapatkan perhatian, misalnya oleh Helgesen and Nesset (2007) yang menyimpulkan bahwa loyalitas dipengaruhi oleh kepuasan, serta image perguruan tinggi dan program studi. Nugroho (2010) yang menghasilkan temuan bahwa kepuasan mahasiswa terhadap proses belajar mengajar berpengaruh positif dan signifikan terhadap terhadap citra dan loyalitas mahasiswa terhadap perguruan tinggi. Kepuasan 
mahasiswa dalam proses belajar mengajar ditentukan oleh dosen sebagai pihak yang memiliki peran sentral dalam proses belajar mengajar. Peningkatan kepuasan mahasiswa dalam kegiatan belajar mengajar haruslah berfokus kepada bagaimana pengelolaan dosen di perguruan tinggi. Saheen et al. (2013) menyatakan staf akademik adalah pilar bagi universitas, sehingga dosen adalah pembangun bangsa, sosok berpendidikan yang bermartabat, yang diharapkan akan menjadi teladan kebajikan sosial seperti kejujuran, integritas, disiplin, pengabdian, martabat, dan berkomitmen. Menurut Kayuni and Tambulasi (2007) kurangnya motivasi dan komitmen para dosen dapat memiliki dampak negatif pada proses belajar mahasiswa

Faktor-faktor kinerja dosen yang telah dilaksanakan di beberapa perguruan tinggi di Indonesia, misalnya oleh Setiawati (2009), Mundarti (2007), Christie (2011), Martono (2013), dan Sulastri (2007) menyatakan bahwa kompetensi dan motivasi kerja para dosen berpengaruh positif dan signifikan terhadap kinerja. Vandenberg and Lane (1992: 153) menyatakan biasanya para staf pengajar atau dosen memiliki tujuan mengajar untuk menikmati pekerjaan yang mereka lakukan dan merasa terpuaskan dengan pekerjaan mereka. Hal tersebut sesuai dengan hasil wawancara penulis dengan beberapa dosen, bahwa mereka senang mengajar dan berinteraksi dengan mahasiswa. Berdasarkan hal tersebut maka penelitian menggunakan pendekatan self determination theory.

Apabila kepuasan mahasiswa dalam proses belajar mengajar merupakan salah satu ukuran kinerja dosen, maka kinerja dosen sebagai pegawai perguruan tinggi sebagaimana dikemukakan oleh Dryer and Reeves dalam Armstrong (2010:38) bahwa kinerja ditentukan oleh kompetensi dan motivasi, sehingga mewujudakan kinerja dosen harus memperhatikan keduanya. Sebagaimana Daft (2010:422) bahwa motivasi mengacu pada kekuatan baik dari dalam maupun dari luar yang membangkitkan antusiasme dan persistensi untuk melakukan sesuatu. Merupakan tugas manajer untuk memotivasi para pegawai untuk mencapai tujuan-tujuan organisasi. Kepemimpinan di perguruan tinggi sebagaimana penelitian oleh Basham (2010) dan Sadeghi et al.(2012) menunjukkan bahwa sebagian besar perguruan tinggi yang sukses menerapkan kepemimpinan transformasional maupun transaksional secara bersama-sama. Namun penelitian oleh Horn-Turpin (2009) menunjukkan bahwa perilaku gaya kepemimpinan 
transformasional terbukti efektif dapat meningkatkan komitmen organisasional maupun kepuasan kerja dari para staf pengajar.

Berdasarkan uraian tersebut di atas maka dapat ditarik suatu pemikiran bahwa kepuasan mahasiswa dalam proses belajar mengajar dapat ditingkatkan melalui pendekatan gaya kepemimpinan yang tepat dan pemahaman motivasi kerja dosen. Pemikiran tersebut merupakan alasan perlunya dilakukan penelitian ini, yakni mengkaji pengaruh gaya kepemimpinan fakultas dan pemenuhan kebutuhan dasar untuk memotivasi para dosen sehingga kepuasan mahasiswa dalam proses belajar mengajar dapat ditingkatkan.

\section{Tujuan Penelitian}

Penelitian memiliki tujuan : 1) Mengkaji dan menganalisis tingkat persepsi para dosen tentang gaya kepemimpinan di fakultas, pemenuhan kebutuhan psikologis dasar, motivasi kerja, dan tingkat kepuasan mahasiswa dalam proses belajar mengajar di Universitas Mercu Buana. 2) Menganalisis pengaruh kepemimpinan terhadap kepuasan kebutuhan psikologis dasar para dosen. 3) Menganalisis pengaruh pemenuhan kebutuhan psikologis dasar terhadap motivasi kerja para dosen. 4) Menganalisis pengaruh kepemimpinan terhadap motivasi kerja. 5) Menganalisis pengaruh motivasi kerja terhadap kinerja dosen dalam proses belajar mengajar. 6) Menganalisis pengaruh kepemimpinan transformasional terhadap kinerja dosen dalam proses belajar mengajar. Dan 7) Menganalisis pengaruh pemenuhan kebutuhan psikologis dasar terhadap kinerja dosen dalam proses belajar mengajar.

\section{Urgensi Penelitian}

Kebijakan dalam organisasi perguruan tinggi biasanya telah terbagi dalam fungsi-fungsi yang dijalankan secara terpisah antara fungsi pemasaran dengan fungsi manajemen sumberdaya manusia. Penelitian ini mengkaitkan antara konsep pemasaran yakni kepuasan mahasiswa dalam proses belajar mengajar dengan konsep menajemen sumberdaya manusia, sehingga diharapkan memberikan suatu manfaat bagi strategi manajemen perguruan tinggi baik dalam mengelola sumberdaya manusia maupun dalam mengelola mahasiswa sebagai pelanggan. 


\section{KAJIAN PUSTAKA DAN KERANGKA PEMIKIRAN}

\section{Kepuasan Pembelajaran dan Loyalitas Mahasiswa}

Konsep kepuasan mahasiswa adalah variabel manajemen penting untuk mencapai tujuan strategis lembaga pendidikan tinggi. Namun masing-masing lembaga bervariasi dalam tolok ukur pengumpulan data mereka mengenai kepuasan mahasiswa (Ramsden, 1991). Menurut Helgesen (2006), loyalitas mahasiswa (customer) berhubungan positif dengan kepuasan mahasiswa dan kinerja jangka panjang dari institusi pendidikan.

\section{Dosen dan Kinerja Pembelajaran}

Tugas dosen terdiri dari pelaksanaan tridharma perguruan tinggi yang terdiri dari: 1) Pembelajaran adalah proses interaksi mahasiswa dengan dosen dan sumber belajar pada suatu lingkungan belajar. 2) Penelitian adalah kegiatan yang dilakukan menurut kaidah dan metode ilmiah secara sistematis untuk memperoleh informasi, data, dan keterangan yang berkaitan dengan pemahaman dan/atau pengujian suatu cabang pengetahuan dan teknologi. 3) Pengabdian kepada Masyarakat adalah kegiatan sivitas akademika yang memanfaatkan ilmu pengetahuan dan teknologi untuk memajukan kesejahteraan masyarakat dan mencerdaskan kehidupan bangsa. Beberapa penelitian terkait motivasi kerja dosen menggunakan pendekatan self-determination theory, sebagaimana penelitian-penelitian oleh Ma (2012), Alvernini and Lucidi (2008), Badri et al. (2014), Silman (2014), serta Barkoukisa et al. (2008).

\section{Kepemimpinan Transformasional}

Kepemimpinan menurut Yukl (2004 : 4) merupakan proses mempengaruhi, yang menentukan intepretasi mengenai peristiwa-peristiwa bagi para pengikut, pilihan dari sasaran-sasaran bagi kelompok atau organisasi, pengorganisasian dari aktivitas-aktivitas kerja untuk mencapai sasaran-sasaran tersebut, motivasi dari para pengikut untuk mencapai sasaran, pemeliharaan hubungan kerja sama dan tim kerja, serta perolehan dukungan dan kerja sama dari orang-orang yang berada di luar kelompok atau organisasi. Sebagaimana Bass dalam Judge and Piccolo (2004) berdasarkan teori kepemimpinan transformasional Burns, melakukan beberapa modifikasi atau elaborasi 
tentang konsep kepemimpinan transformasional. Versi terbaru tentang kepemimpinan transformasional terdapat lima dimensi yakni karisma atau pengaruh ideal yang terdiri dari atribusi dan keperilakuan, motivasi inspirasional, stimulasi intelektual, dan pertimbangan individual.

\section{Motivasi Kerja Dosen dan Teori Self Determination}

Motivation, kata Latin movere yang berarti bergerak, adalah aktivasi atau energization perilaku berorientasi tujuan (Wikipedia, 2010). Nelson dan Quick (2003) menyatakan bahwa motivasi adalah proses membangkitkan dan mempertahankan perilaku yang diarahkan pada tujuan. Namun, Luthans (2012) melihatnya sebagai proses yang membangkitkan, memberikan energi, mengarahkan, dan memelihara perilaku dan kinerja. Ryan dan Deci dalam Compton (2005: 35) menyatakan bahwa individuindividu yang termotivasi secara intrinsik cenderung memperlihatkan ketahanan, kreativitas, self-esteem, vitalitas, dan kesejahteraan yang lebih tinggi dibandingkan dengan individu-individu yang termotivasi oleh imbalan eksternal atau motivasi ekstrinsik. Perilaku seseorang bergerak dari kontinum nonself-determined ke arah selfdetermined. Motivasi tersebut dapat dilihat dalam bentuk gaya regulasi motivasi (regulation styles), yang meliputi: 1) Non-regulation (berasal dari amotivation), 2) External regulation (berasal dari extrinsic motivation), 3) Identified regulation (berasal dari extrinsic motivation), dan 4) Intrinsic regulation (berasal dari intrinsic motivation).

\section{Kebutuhan Psikologis Dasar}

Satu set faktor yang relevan dengan motivasi mengacu pada kebutuhan dasar. Self Determination Theory (SDT) mengasumsikan tiga kebutuhan dasar manusia yang terlibat dalam penentuan nasib sendiri yang memotivasi orang untuk memulai perilaku: (1) kebutuhan untuk otonomi, yang merupakan persepsi mengalami rasa pilihan dan kebebasan psikologis dalam inisiasi dan keterlibatan berkelanjutan dalam tindakan seseorang, (2) kebutuhan kompetensi, yang merupakan persepsi yang efektif dalam menangani lingkungan, dan (3) kebutuhan akan keterkaitan, yang merupakan rasa dirawat dan terhubung ke orang lain (Baumeister \& Leary, 1995). Secara khusus, telah menunjukkan bahwa kepuasan kebutuhan kompetensi dan otonomi mendasari baik motivasi intrinsik dan proses internalisasi. Kepuasan kebutuhan keterkaitan telah 
terbukti juga penting untuk internalisasi. Tingkat kepuasan dari kebutuhan untuk otonomi memainkan peran sangat penting karena hal inilah yang membedakan apakah terjadi identifikasi atau integrasi, bukan hanya sekedar introjeksi (Gagne and Deci, 2005).

\section{Kerangka Pemikiran dan Hipotesis}

Kerangka pemikiran penelitian yang digambarkan sebagai hubungan antar variabel disampaikan pada Gambar 1.

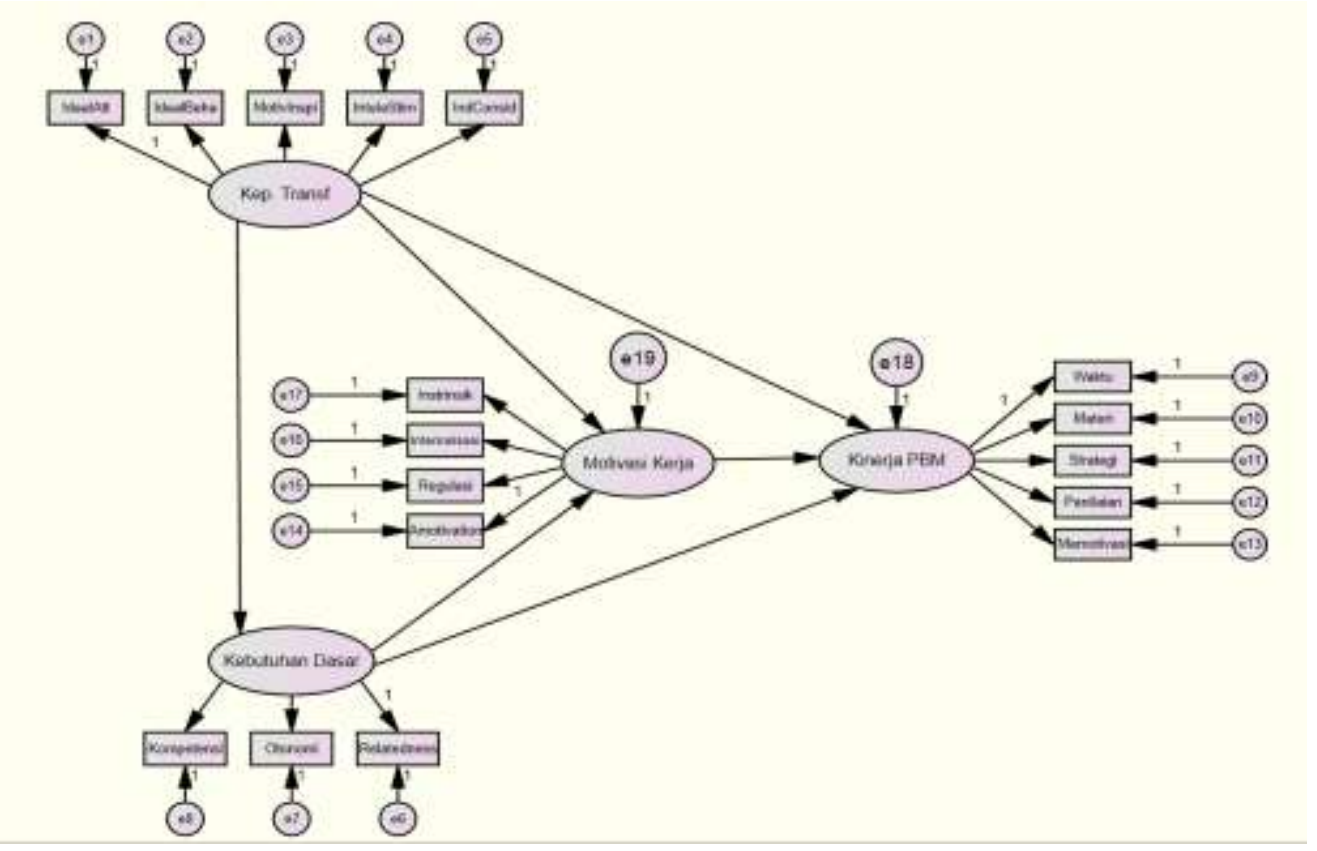

\section{Gambar 1. Kerangka Pemikiran}

\section{Hipotesis Penelitian :}

1. Kepemimpinan transformasional berpengaruh signifikan terhadap motivasi kerja dosen.

2. Kepuasan kebutuhan dasar dosen berpengaruh signifikan terhadap motivasi kerja dosen.

3. Motivasi kerja dosen berpengaruh signifikan terhadap kinerja dosen dalam proses belajar mengajar.

4. Kepemimpinan transformasional berpengaruh signifikan terhadap kinerja dosen dalam proses belajar mengajar.

5. Kepuasan kebutuhan dasar dosen berpengaruh signifikan terhadap kinerja dosen dalam proses belajar mengajar. 


\section{METODE PENELITIAN}

\section{Rancangan Penelitian, Populasi dan Sampel Penelitian}

Penelitian merupakan penelitian penjelasan (explanatory research) karena bertujuan untuk menjelaskan pengaruh antara variabel melalui pengujian hipotesis. Hipotesis disusun berdasarkan teori dan penelitian terdahulu. Populasi penelitian adalah seluruh karyawan dosen di Universitas Mercu Buana Jakarta, berjumlah 567 orang. Pengambilan sampel dilaksanakan secara proporsional, dengan jumlah sampel ditetapkan sebanyak 150 orang dosen dengan dasar pertimbangan bahwa menurut Hier et al. (2012) jumlah sampel adalah 5 sampai dengan 10 kali jumlah variabel. Namun kuisoner yang kembali kepada peneliti dan layak untuk dianalisis sebanyak 51 kuisoner. Hal ini menyebabkan pelaksanaan analisis data tidak dapat dilakukan dengan structural equation modeling (SEM) namun dengan analisis jalur (path analysis). Data diolah dengan menggunakan analisis jalur (path analysis) dan diolah menggunakan paket program AMOS (Analysis of Moment Structure) versi 17.

\section{Uji Validitas dan Reliabilitas}

Uji validitas dilaksanakan untuk menguji apakah pernyataan-pernyataan dalam kuisoner benar mengukur variabel yang digunakan dalam penelitian. Kriteria pengujian validitas berdasarkan korelasi product moment dari skor pertanyaan dengan total skor variabel. Jika nilai korelasi tersebut signifikan pada tingkat kepercayaan lebih kecil 0,05 persen maka pernyataan tersebut valid. Uji reliabilitas dilakukan untuk menguji konsistensi jawaban responden atas kuisoner yang digunakan dalam penelitian. Kriteria pengujian reliabilitas berdasarkan nilai Cronbach Alpha sebesar 0,6. Jika nilai Cronbach Alpha lebih besar dari 0,6 maka instrumen penelitian reliabel.

\section{Uji Keseuaian Model}

Kriteria Goodness-of-Fit mengukur kesesuaian input observasi atau sesungguhnya (matrik kovarian atau korelasi) dengan prediksi dari model yang diajukan (proposed model). Terdapat tiga jenis ukuran Goodness-of-Fit yang akan digunakan dalam penelitian, absolute fit measure, incremental fit measure, dan parsimonious fit measure. (Ferdinand (2006:92) 


\section{Uji Signifikansi Model Struktural dan Pengujian Hipotesis}

Pengujian dilakukan dengan menggunakan uji t. Tingkat signifikansi hubungan antar variabel dilakukan dengan melihat nilai P (tingkat signifikansi) dan CR masingmasing hubungan antar variabel. Signifikansi bisa dilihat berdasarkan nilai critical ratio atau CR, yakni bila CR lebih besar atau sama dengan 2,00 maka maka hubungan antar variabel adalah signifikan (Haier et al. dalam Ferdinant (2002:145)).

\section{HASIL PENELITIAN DAN PEMBAHASAN}

\section{Karakteristik Responden}

Karakteristik responden yang menjadi sampel penelitian menunjukkan bahwa berdasarkan jenis kelamin terdapat suatu keseimbangan jumlah antara dosen laki-laki dan perempuan, namun dosen perempuan relatif lebih banyak yakni 53\%. Hal tersebut menunjukkan bahwa profesi sebagai dosen, meskipun tidak dominan, lebih merupakan pilihan bagi responden perempuan. Berdasarkan pengelompokan usia responden, maka dosen pada kelompok usia > 40 tahun sampai dengan usia 50 tahun merupakan proporsi yang paling besar, yakni sebesar 48 persen. Kelompok usia selanjutnya adalah <30 tahun sampai 40 tahun sebanyak 32 persen, sedangkan yang memiliki usia > 50 tahun sebanyak 20persen.

Pendidikan dosen yang paling banyak adalah S2 dengan proporsi 67 persen, sedangkan sebanyak 33 persen memiliki pendidikan S3. Hal tersebut dapat diartikan bahwa sebagian besar responden memiliki jenjang pendidikan S2. Masa kerja yang paling banyak dari responden adalah kurang dari 5 tahun yakni sebanyak 55 persen. Proporsi selanjutnya adalah masa kerja di atas 10 tahun sebanyak 23 persen, sedangkan antara 5 tahun sampai dengan 10 tahun sebanyak 22 persen responden. Dapat disimpulkan bahwa responden penelitian didominasi dosen dengan masa kerja kurang dari 5 tahun sebanyak 55 persen, sehingga mereka masih memiliki waktu untuk dikembangkan lebih lanjut sebagai dosen di UMB.

\section{Statistik Deskriptif Jawaban Responden}

\section{Kepemimpinan Transformasional}

Dimensi-dimensi kepemimpinan transformasional berdasarkan persepsi para dosen menunjukkan skor lebih besar dari 3 namun lebih kecil dari 4, dengan kisaran 
paling tinggi sebesar 3,9675 pada dimensi motivasi inspirasional dan paling rendah dengan skor 3,3469 pada dimensi pertimbangan individu. Hal tersebut mengindikasikan bahwa sebagian besar para dosen menyatakan setuju bahwa para pimpinan menampilkan perilaku-perilaku transformasional. Skor penilaian tersebut memiliki makna bahwa para pimpinan fakultas di UMB memiliki perilaku menonjol pada sikap keteladanan (idealized influence attribution).

\section{Pemenuhan Kebutuhan Dasar}

Dimensi-dimensi pemenuhan kebutuhan dasar berdasarkan persepsi para dosen menunjukkan skor lebih besar dari 3 namun lebih kecil dari 4, dengan kisaran paling tinggi sebesar 3,9804 pada dimensi keterikatan, dan paling rendah dengan skor 3,5106 pada dimensi otoritas, sedangkan dimensi otoritas memiliki skor 3,9610. Hal tersebut mengindikasikan bahwa sebagian besar para dosen menyatakan setuju bahwa kebutuhan mereka akan keterikatan dan kompetensi maupun otoritas namun masih ada yang menyatakan tidak terpenuhi atau netral. Skor penilaian tersebut memiliki makna bahwa pemenuhan kebutuhan dasar para dosen masih dapat ditingkatkan baik pada dimensi kompetensi, otoritas maupun keterikatan.

\section{Motivasi Kerja}

Dimensi-dimensi motivasi kerja berdasarkan persepsi para dosen menunjukkan skor lebih besar dari 4 pada dimensi motivasi intrinsik dan identified regulation, namun lebih kecil dari 4 untuk dimensi external regulation dan amotivation. Nilai skor rata-rata untuk dimensi motivasi intrinsik sebesar 4,5539 sedangkan skor rata-rata untuk dimensi identified regulation sebesar 4,3922. Hal tersebut mengindikasikan bahwa sebagian besar para dosen dalam bekerja didorong oleh motivasi intrinsik serta identified regulation. Skor penilaian tersebut memiliki makna bahwa para dosen memiliki dorongan yang berlandaskan pada nilai-nilai luhur pekerjaan sebagai dosen serta memahami bahwa pekerjaan mereka harus dilaksanakan dengan sebaik mungkin karena telah menjadi konsekuensi dari profesi yang mereka pilih. Sebagaimana dikemukakan Ryan dan Deci dalam Compton (2005: 35) bahwa individu-individu yang termotivasi secara intrinsik cenderung memperlihatkan ketahanan, kreativitas, self-esteem, vitalitas, dan kesejahteraan yang lebih tinggi dibandingkan dengan individu-individu yang 
termotivasi oleh imbalan eksternal atau motivasi ekstrinsik. Berarti para dosen di UMB memiliki motivasi yang baik dan menunjang kinerja.

\section{Kinerja Dosen dalam Proses Belajar Mengajar (PBM)}

Kinerja dosen dalam proses belajar mengajar (PBM) diukur dengan menggunakan 4 dimensi, yakni pengelolaan waktu, penyampaian materi, strategi pengajaran, penilaian, dan memotivasi mahasiswa. Statistik deskriptif menunjukkan bahwa keseluruhan skor pada 4 dimensi tersebut di atas 3, namun masih lebih kecil dari 3,25. Berarti secara rata-rata kinerja dosen dalam PBM sudah baik, namun masih belum mencapai target universitas sebesar 3,25. Jika diperhtaian nilai rata-rata kinerja PBM pada setiap dimensinya, maka strategi pengajaran memiliki skor yang paling rendah yakni sebesar 2,14 sedangkan skor paling tinggi pada dimensi memotivasi mahasiswa. Upaya peningkatan skor kinerja PBM masih perlu dilakukan, terutama pada dimensidimensi penilaian, pengelolaan waktu, dan penyampaian materi.

\section{Hasil Uji Validitas dan Reliabilitas Instrumen}

Hasil pengujian validitas dan reliabilitas terhadap alat ukur variabel-variabel kepemimpinan transformasional, pemenuhan kebutuhan psikologis dasar, dan kinerja proses belajar mengajar menunjukkan bahwa instrumen penelitian adalah valid dan reliabel. Hasil pengujian validitas dan reliabilitias untuk variabel motivasi kerja dengan dimensi-dimensi motivasi kerja intrinsik, internal regulation, axternal regualation dan amotivation menunjukkan nilai-nilai koefisien korelasi yang tidak signifikan serta nilai Cronbach Alpha yang lebih kecil dari 0,3. Hal tersebut menunjukkan bahwa keempat macam motivasi tersebut merupakan konsep yang berbeda. Untuk itu maka pengujian validitas dan reliabilitas dilakukan pada setiap jenis motivasi secara terpisah. Respesifikasi model kemudian dilakukan dengan terlebih dahulu melakukan pengujian korelasi antara variabel kinerja PBM dengan keempat motivasi, dimana hanya motivasi intrinsik yang memiliki korelasi yang signifikan dengan kinerja PBM. Berdasarkan hal tersebut maka untuk analisis selanjutnya hanya motivasi intrinsik yang dimasukkan ke dalam model penelitian. Keseluruhan pengukuran menunjukkan bahwa kesemua 
pengukuran variabel penelitian valid dan reliabel sehingga dapat digunakan dalam penelitian.

\section{Hasil Uji Asumsi Klasik}

Hasil pengujian asumsi menunjukkan terjadinya beberapa pelanggaran asumsi terutama pada asumsi normalitas data, namun masih dalam batas bisa diterima karena tidak lebih dari 10 persen. Berdasarkan hal tersebut maka model analisis penelitian dinilai memadai untuk dilaksanakan.

\section{Hasil Uji Kelayakan Model}

Hasil pengujian menunjukkan beberapa kriteria kelayakan model kurang baik, namun beberapa indeks kelayakan model menunjukkan nilai yang baik dan cukup baik. Berdasarkan hal tersebut maka model masih diterima mengingat terdapat 5 indeks yang baik, dan satu cukup baik. Peningkatan nilai ketepatan model bisa ditingkatkan melalui modifikasi model penelitian atau dengan menghilangkan data pencilan, namun hal tersebut tidak dilakukan mengingat model telah cukup memadai.

\section{Hasil Pengujian Hipotesis}

Hasil pengujian hipotesis 1 bahwa kepemimpinan transformasional berpengaruh signifikan terhadap motivasi intrinsik menunjukkan nilai CR yang lebih kecil dari 2, sehingga hipotesis ditolak. Berarti tidak terbukti bahwa kepemimpinan tranformasional berpengaruh positif dan signifikan terhadap motivasi intrinsik. Hasil penelitian ini tidak sesuai dengan penelitian terdahulu yang dilakukan oleh Goodridge (2007) yang menghasilkan temuan bahwa kepemimpinan transformasional berpengaruh terhadap motivasi otonomous dari para anak buah, yaitu motivasi yang berasal dari dalam diri seseorang. Hasil penelitian ini menunjang penelitian oleh Herminingsih (2012) yang menyatakan bahwa kepemimpinan transformasional tidak berpengarih signifikan untuk meningkatkan komitmen para dosen UMB.

Hasil pengujian hipotesis 2 bahwa pemenuhan kebutuhan dasar berpengaruh positif terhadap motivasi intrinsik menunjukkan nilai CR sebesar 2,424 yang lebih besar dari 2, sehingga hipotesis diterima. Berarti terbukti bahwa pemenuhan kebutuhan dasar berpengaruh positif dan signifikan terhadap motivasi intrinsik. Semakin tinggi 
pemenuhan kebutuhan dasar yang terdiri dari kompetensi, otoritas, dan keterikatan maka semakin tinggi motivasi intrinsik dosen. Hasil penelitian ini mendukung penelitian-penelitian terdahulu oleh Silman (2014) meneliti hubungan antara kepuasan kebutuhan dasar yang berhubungan dengan pekerjaan dan keterlibatan kerja. Zhang et al. (2011) yang menyatakan bahwa persepsi dari pemenuhan otonomi, kompetensi, dan keterkaitan memfasilitasi terbentuknya motivasi intrinsik dan akhirnya positif memprediksi kinerja aktivitas siswa. Temuan penelitian ini mendukung prinsip self determination theory.

Hasil pengujian hipotesis 3 bahwa motivasi intrinsik berpengaruh signifikan terhadap kinerja dosen dalam proses belajar mengajar menunjukkan nilai CR sebesar 2,245 yang lebih besar dari 2, sehingga hipotesis diterima. Berarti terbukti bahwa motivasi intrinsik berpengaruh positif dan signifikan terhadap kinerja dosen dalam proses belajar mengajar. Semakin tinggi motivasi intrinsik dosen semakin baik kinerja dosen dalam proses belajar mengajar. Hasil penelitian ini mendukung penelitianpenelitian terdahulu oleh Badri et al. (2014) menunjukkan dengan analisis jalur menunjukkan bahwa pemenuhan kebutuhan psikologis dasar dan motivasi intrinsik berpengaruh positif terhadap prestasi akademik. Hasil penelitian Abbas (2013) pada para guru juga menyimpulkan bahwa motivasi intrinsic memiliki pengaruh yang signifikan terhadap kinerja guru, sedangkan motivasi ekstrinsik dan kompetensi tidak berpengaruh signifikan terhadap kinerja guru. Hasil penelitian ini berbeda dengan hasil penelitian Akbar (2013) yang melakukan penelitian di PTP Perkebunan di Surabaya yang menyatakan bahwa baik motivasi intrinsic maupun motivasi ekstrinsik berpengaruh signifikan terhadap kinerja karyawan.

Hasil pengujian hipotesis 4 bahwa kepemimpinan transformasional berpengaruh signifikan terhadap kinerja dosen dalam proses belajar mengajar menunjukkan nilai CR yang lebih kecil dari 2, sehingga hipotesis ditolak. Berarti tidak terbukti bahwa kepemimpinan tranformasional berpengaruh terhadap kinerja dosen dalam proses belajar mengajar. Hasil penelitian ini tidak sesuai dengan penelitian-penelitian terdahulu yang menunjukkan efektivitas kepemimpinan transformasional dalam meningkatkan kinerja pegawai, sebagaimana dilakukan Hukpati (2009), Horn-Turpin (2009), Niekerk (2005), Sadeghi et al. (2012), maupun Basham (2010), serta Thamrin (2012) 
menyatakan bahwa kepemimpinan transformasional memiliki pengaruh signifikan positif baik langsung maupun tidak langsung terhadap kinerja karyawan.

Hasil pengujian hipotesis 5 bahwa pemenuhan kebutuhan dasar dosen terhadap kinerja dosen dalam proses belajar mengajar menunjukkan nilai CR yang lebih kecil dari 2, sehingga hipotesis ditolak. Berarti tidak terbukti bahwa pemenuhan kebutuhan dasar dosen berpengaruh terhadap kinerja dosen dalam proses belajar mengajar. Hasil penelitian ini tidak sesuai dengan penelitian terdahulu yang dilakukan oleh Ghazi and Khan (2013) menyatakan bahwa pemenuhan kebutuhan dasar guru memiliki korelasi positif dengan kinerja akademik guru sehingga merekomendasikan bahwa untuk peningkatan mutu pendidikan, maka para guru perlu disediakan lingkungan kerja di mana kebutuhan dasar mereka dapat terpenuhi.

\section{KESIMPULAN DAN SARAN}

\section{Kesimpulan}

1. Kepemimpinan transformasional tidak berpengaruh signifikan terhadap motivasi intrinsik dosen.

2. Pemenuhan kebutuhan psikologis dasar berpengaruh positif dan signifikan terhadap motivasi intrinsik dosen.

3. Motivasi intrinsik berpengaruh positif dan signifikan terhadap kinerja proses belajar mengajar (PBM) dosen.

4. Kepemimpinan transformasional tidak berpengaruh signifikan terhadap kinerja proses belajar mengajar (PBM) dosen.

5. Pemenuhan kebutuhan psikologis dasar tidak berpengaruh terhadap kinerja proses belajar mengajar (PBM) dosen.

6. Berdasarkan hasil pengujian hipotesis yang menghasilkan kesimpulan 1 sampai dengan 5 maka dapat ditarik kesimpulan secara keseluruhan bahwa peningkatan kinerja proses belajar mengajar (PBM) dapat ditingkatkan melalui pemenuhan kebutuhan psikologis dasar pada dosen berupa peningkatan kompetensi, otonomi, dan keterikatan dimana selanjutnya berpengaruh terhadap motivasi intrinsik dosen sebagai variabel intervening. 


\section{Saran}

Berdasarkan kesimpulan yang dihasilkan maka penelitian ini menyarankan agar peningkatan kinerja belajar mengajar para dosen ditingkatkan melalui penyediaan lingkungan kerja serta kebijakan yang membangun kompetensi para dosen, pemberian otonomi kepada para dosen dalam melaksanakan proses perkuliahan serta dengan memberikan rasa keterikatan antar sesama dosen sebagai rekan kerja.

\section{DAFTAR PUSTAKA}

Armstrong, Michael. 2010. Strategic Human Resource Management A Guide to Action. Kogan Page Limited. London.

Badri, Rahim, Javad Amani-Saribaglou, Ghafour Ahrari, Navideh Jahadi, Hojjat Mahmoudi.2014. School Culture, Basic Psychological Needs, Intrinsic Motivation and Academic Achievement: Testing a Casual Model. Mathematics Education Trends and Research 2014 (2014) 1-13

Barkoukisa, Vassilis, Haralambos Tsorbatzoudis, George Grouiosa and Georgios Sideridis. 2008. The assessment of intrinsic and extrinsic motivation and amotivation: Validity and reliability of the Greek version of the Academic Motivation Scale. Assessment in Education: Principles, Policy \& Practice Vol. 15, No. 1, pp: 39-55.

Basham, Lloyd Moman. 2010. Transformational And Transactional Leaders In Higher Education. International Review of Business Research Papers. Volume 6. Number 6, pp:141 -152.

Brien, Maryse, Jacques Forest, Geneviève A. Mageau and Jean-Sébastien Boudrias, Pascale Desrumaux, Luc Brunet, and Estelle M. Morin.2012. The Basic Psychological Needs at Work Scale: Measurement Invariance between Canada and France. Applied Psychology : Health and Well-being, Vol.4, No.2, pp: 167187.

Daft, Ricahrd L. 2002. The Leadership Experience. Second Edition. Thomson South Western. Singapore.

Hair, Jr., J. F., Black, W. C., Babin, B. J., Anderson, R. E., \& Tatham, R. L. (2006). Multivariate Data Analysis (6th ed.). Upper Saddle River, NJ: Pearson Prentice Hall.

Horn-Turpin, Frances D., 2009. A Study Examining the Effects of Transformational Leadership Behaviors on theFactors of Teaching Efficacy, Job Satisfaction and Organizational Commitment as Perceived by Special Education Teachers. 
Hukpati, Colette Ama, 2009. Transformational Leadership and Teacher Job Satisfaction : A Comparative Study of Private and Public Tertiary Institutions in Ghana. Master Degree in Educational Science and Technology Educational Management, Evaluation and Assessment Faculty of Behavioural Science University of Twente

Judge, Timothy A. and Ronald F. Piccolo. 2004. Transformational and Transactional Leadership: A Meta-Analytic Test of Their Relative Validity. Journal of Applied Psychology. Vol. 89, No. 5, pp: 755-768.

Kayuni.H. and Tambulsai,R (2007). Teacher turnover in Malawi's Ministry of Education: Realities and challenges.International Education Journal, 2007, 8(1), 89-99.

Mundarti (2007) Faktor-Faktor yang Mempengaruhi Kinerja Dosen dalam Melaksanakan Proses Belajar Mengajar di Prodi Kebidanan Magelang Politeknik Kesehatan Semarang Tahun Akademik 2005/2006. Masters thesis, program Pascasarjana Universitas Diponegoro.

Mustapha, Noraani and Wee Yu Ghee. 2013. Examining Faculty Workload as Antecedent of Job Satisfaction among Academic Staff of Higher Public Education in Kelantan, Malaysia . Business and Management Horizons. Vol.1, No.1. pp:1-15.

Niekerk, Magdalena Maria Van. 2005. Transformational Leaderhip at a Higher Education Institution. Tesis Master of Arts Industrial and Organisational Psychology at the University of South Africa.

Nugroho, Arissetyanto. (2010). Analisis Keterkaitan antara Kepuasan Proses Belajar Mengajar, Citra dan Loyalitas Perguruan Tinggi. Disertasi Institut Pertanian Bogor. Bogor.

Prasetyaningrum, Indah Dwi. 2009. Analisis Pengaruh Pembelajaran dan Kualitas Pelayanan terhadap Kepuasan Mahasiswa dan Loyalitas Mahasiswa (Studi Kasus pada Undaris Ungaran). Tesis Magister Manajemen Program Studi Magister Manajemen Universitas Diponegoro. Semarang.

Robbins, Stephen P. and Timothy A. Judge. 2013. Organizational Behavior. Boston. Pearson.

Sadeghi, Amir, Zaidatol Akmaliah, and Lope Pihie. 2012. Transformational Leadership and Its Predictive Effects on Leadership Effectiveness. International Journal of Business and Social Science .Vol. 3 No. 7, pp: 1-12.

Shaheen, Imrab, Mushtaq A.Sajid, and Qudsia Batool.2013. Factors Affecting the Motivation of Academic Staff (A case study of University College Kotli,UAJ\&K. International Journal of Business and Management Invention.Vol.2 No.1. pp:105-112. 
Silman, Fatos. 2014. Work-related basic need satisfaction as a predictor of work engagement among academic staff in Turkey. South African Journal of Education, Volume 34, Number 3, pp: 1-5.

Van den Broeck, Anja, Maarten Vansteenkiste, Hans De Witte, Bart Soenens, and and Willy Lens. 2010. Capturing autonomy, competence, and relatedness at work: Construction and initial validation of the Work-related Basic Need Satisfaction scale. Journal of Occupational and Organizational Psychology. Vol, 83, 9811002.

Visser, C.F. (2010). Self-Determination Theory Meets Solution-Focused Change: Autonomy, Competence and Relatedness Support In Action, InterAction - The Journal of Solution Focus in Organisations, Volume 2, Number 1, May 2010 , pp. 7-26(20).

Yukl, Garry. (2006), Leadership in Organizations, 4th ed., Prentice Hall, Upper Saddle River, NJ. 